\title{
Small-scale spatial variability of food partitioning between cultivated oysters and associated suspension- feeding species, as revealed by stable isotopes
}

\author{
Stanislas Dubois ${ }^{1, *}$, Francis Orvain ${ }^{1}$, Julio César Marin-Léal ${ }^{1}{ }^{,}$Michel Ropert ${ }^{2}$, \\ Sébastien Lefebvre ${ }^{1}$ \\ ${ }^{1}$ Laboratoire de Biologie et Biotechnologies Marine, Université de Caen, Esplanade de la Paix, 14032 Caen cedex, France \\ ${ }^{2}$ Laboratoire Environnement Ressource de Normandie, IFREMER, Avenue du Général de Gaulle, BP 32, \\ 14520 Port en Bessin, France
}

\begin{abstract}
Oyster culture structures support a host of epibionts belonging to the same suspensionfeeding guild, which are considered to be potential competitors for food with cultivated oysters. In an intertidal shellfish ecosystem on the northern French coast, an approach based on stable isotopes $\left({ }^{13} \mathrm{C}\right.$ and $\left.{ }^{15} \mathrm{~N}\right)$ was used to investigate intra- and interspecific food resource partitioning among cultivated oysters and the main associated wild sessile epibionts such as polychaetes, barnacles, mussels and ascidians. The main objective of the present study was to determine inter- and intraspecific food partitioning, along with small-scale spatial variability, within the guild of suspension feeders. We demonstrated that interspecific competition was limited among co-occurring suspension-feeders (ascidians, serpulid and terebellid polychaetes, bivalves and barnacles). None of the studied species had similar $\delta^{13} \mathrm{C}$ and $\delta^{15} \mathrm{~N}$ signatures, indicating that relative contributions of organic matter sources may differ for each suspension-feeding species. Spatial variability was investigated both from the view of intra- and interspecific variability. Intraspecific variability was examined with regard to species' feeding biology and the trophic plasticity of co-occurring suspension-feeders. Mantel tests indicated that spatial heterogeneity resulted not only from environmental conditions, such as elevation above sea level (a.s.l.) and sediment features, but also from the inherent spatial structure of isotopic signatures. Our results show that isotopic approaches that are limited to sampling in one area and at one time are at risk of mistaking trophic interactions.
\end{abstract}

KEY WORDS: Shellfish · Oysters $\cdot$ Sessile epibionts $\cdot$ Stable isotopes $\cdot$ Spatial variability $\cdot$ Trophic plasticity

Resale or republication not permitted without written consent of the publisher

\section{INTRODUCTION}

In many estuarine and coastal ecosystems, commercial farming of shellfish is an important industry (Crawford et al. 2003). The carrying capacity of shellfish ecosystems has been investigated with models that assumed these species to feed in the same trophic niche and compete for the same food resources (see review by Prins et al. 1998). In particular, shellfish culture structures are known to support a range of associated organisms (mainly suspension-feeders), generally found on surrounding hard substrata and suspected of competing with farmed species for food (Lesser et al. 1992).

Analysis of gut contents has been used to differentiate the diets of bivalve species, but numerous constraints (small size of consumers, high uncertainty of many microalgal identifications, difficulty of linking ingested and assimilated food) have compelled scientists to develop parallel and more accurate tools to understand food-web structure. Since it was shown that diet and trophic relationships among organisms could be inferred from comparisons of natural abundances of stable isotopes with those in consumers' 

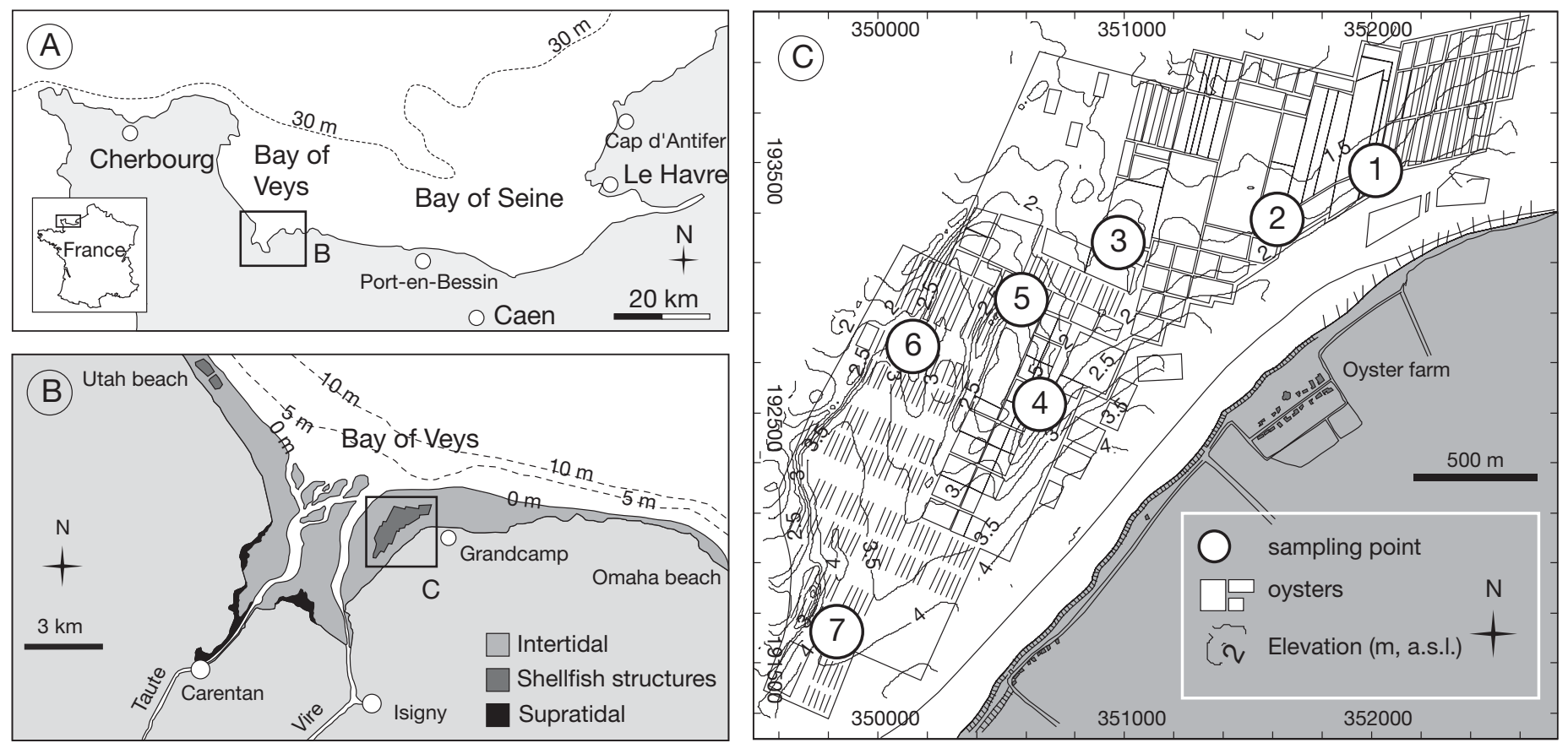

Fig. 1. (A) Location of the Bay of Veys on the northern French coast, (B) detail of the Bay of Veys (dashed lines: depth), (C) 7 sampling sites within the Bay of Veys. a.s.l.: above sea level. Coordinates in NTF (system) Lambert II (projection)

tissues (DeNiro \& Epstein 1978), stable isotopes have increasingly been used to identify organisms' diets and potential food resources (Fry 2006). The carbon and nitrogen isotopic compositions of consumer tissues are thus functions of the ratios of ${ }^{13} \mathrm{C}$ to ${ }^{12} \mathrm{C}\left(\delta^{13} \mathrm{C}\right)$ and ${ }^{15} \mathrm{~N}$ to ${ }^{14} \mathrm{~N}\left(\delta^{15} \mathrm{~N}\right)$ of each food resource, the relative proportion of each food source assimilated, and isotopic fractionation, as defined by step-wise enrichment at each trophic level (Vander Zanden \& Rasmussen 2001).

Few studies have focused on oyster diets using the stable isotopic approach (e.g. Riera \& Richard 1996, Riera 1998, Hsieh et al. 2000), and even less information is available on food competition between farmed oysters and their potential competitors. Food competition between oysters Crassostrea gigas and the invasive gastropod Crepidula fornicata was investigated using $\delta^{13} \mathrm{C}$ and $\delta^{15} \mathrm{~N}$ analysis (Riera et al. 2002); however, there are few data concerning common sessile epibionts - such as mussels, barnacles, serpulids or ascidians - associated with farmed oysters.

Although several studies have already shown that isotopic signatures of resources and consumers may vary greatly over time (Rolff 2000), evidence of spatial variation is scarce because many studies are limited to a single sampling site (e.g. Kharlamenko et al. 2001, Riera et al. 2002). Typically, large-scale spatial variations have been analysed, such as between 2 interconnected but different ecosystems (Marguillier et al. 1997), between upper and lower shores of an entire estuarine ecosystem (Deegan \& Garritt 1997, Hsieh et al. 2002), or along a river gradient (Kikuchi \& Wada 1996). To our knowledge, the only previous study of small-scale spatial variability dealt with species associated with seagrass meadows in a semi-enclosed Mediterranean basin (Vizzini \& Mazzola 2006).

The aim of our study was to analyze small-scale spatial variability of food partitioning between cultivated oysters and associated wild sessile epibionts in an intertidal shellfish ecosystem, using a dual stable isotope approach $\left(\delta^{13} \mathrm{C}\right.$ and $\left.\delta^{15} \mathrm{~N}\right)$. We included classic epibionts such as barnacles and serpulids and other common sessile suspension-feeders that were attached to the rearing structures (ascidians and mussels), in addition to terebellids living in soft sediments beneath the oyster cultures.

\section{MATERIALS AND METHODS}

Study area. The Bay of Veys is located in the western part of the Bay of Seine within the eastern English Channel (Fig. 1). The sandy subtidal area is approx. $80 \mathrm{~km}^{2}$, with a tidal range of $8 \mathrm{~m}$ (macrotidal, semidiurnal regime) during spring tides and a depth of $<20 \mathrm{~m}$ at low tide. The area of oyster-rearing structures $\left(3 \mathrm{~km}^{2}\right)$ is located in the intertidal area (approx. $40 \mathrm{~km}^{2}$ ), which is dominated by soft sediments with some inclusions of hard substrata in the eastern part. 
This macrotidal estuary is characterized by inputs of freshwater coming mainly from the Vire river, which contributes an average discharge of $19 \mathrm{~m}^{3} \mathrm{~s}^{-1}$.

Sampling strategy. Oyster farming covers about $3 \mathrm{~km}^{2}$ in the eastern intertidal part of the bay. Typically, oysters are reared off-bottom in plastic culture bags on iron tables. Our sampling area was small compared with the whole estuarine ecosystem (Fig. 1). At this small scale, as defined by the oyster-culture structures, 7 sampling sites were selected to span the widest extent of the structures. Sampling sites were determined according to 2 environmental variables (Table 1): (1) elevation above sea level (a.s.l. i.e. above mean spring low water), which is directly related to the time available for feeding, and (2) percentage of mud (particles $<65 \mu \mathrm{m}$ ) in the surface $10 \mathrm{~cm}$ of sediments, which is directly correlated with local turbidity and benthic microalgal biomass (van de Koppel et al. 2001). Those 2 parameters were of primary importance in spatial variations in production of the oyster Crassostrea gigas in the same area (Costil et al. 2005), and were related to variations in $\delta^{13} \mathrm{C}$ and $\delta^{34} \mathrm{~S}$ values of consumers in a tidal flat estuary (Hsieh et al. 2002). All sites were located between +1.65 and +2.20 m a.s.l. except Site 7 , which was $+3.50 \mathrm{~m}$ (Table 1). Sites 1 and 2 were on hard substrata, and other sites were on soft-bottom.

Specimens from each selected site were collected in April 2005 and included Pacific oysters Crassostrea gigas and the main associated sessile epifauna, namely the common mussel Mytilus edulis, the acorn barnacle Elminius modestus, the polychaete tubeworm Pomatoceros lamarcki, the polychaete sand mason worm Lanice conchilega and the sea squirt Ascidiella aspersa. Oysters were sampled from culture bags that had not been moved for at least 1 yr. Other epibionts, i.e. $M$. edulis, E. modestus, P. lamarcki and A. aspersa, were scraped from the plastic bags or oyster shells themselves. Polychaetes were collected with a TASM corer (40 cm core depth; Ropert \& Dauvin 2000) from beneath the oyster bags. Occasionally, 1 or 2 species did not occur at a sampling site (Table 1).
Owing to hydrodynamic advection, dispersion and sediment resuspension, suspension-feeders in this intertidal ecosystem fed on a mixture of organic matter originating from 3 main point sources that are mixed by tides twice daily over the study area (Lundsgaard \& Olesen 1996). First, marine water coming from the open sea provided marine suspended particulate organic matter (POM) that was mainly composed of phytoplankton. Second, river inputs supplied suspended terrestrial organic matter (TOM) composed of detritus and freshwater microalgae. Third, wave and tidal action resuspended organic matter from the 2 previous sources and from green macroalgae detritus (hereafter green algae Ulva sp.; ULV) and microphytobenthos (MPB). Due to currents, marine and terrestrial water bodies are well-mixed and hence assumed to be homogeneous in isotopic signatures with regard to both POM and TOM. We assumed that sedimented organic matter that was resuspended each tide was mostly located in a restricted area (around Site 4), as correlated with the percentage of mud (Table 1; see also van de Koppel 2001). At this scale, isotopic signatures of ULV and MPB in sediments were assumed to be spatially homogenous (Guest \& Connolly 2004, Vizzini \& Mazzola 2006). Therefore, potential mixture variations in isotopic signatures over the study area resulted from variations in the food source composition of the mixture and not from spatial variation of the isotopic signature of 1 food source.

Food resources were sampled every 2 mo for $1 \mathrm{yr}$ before specimen collection. POM from marine and terrestrial origins was sampled where these sources were undiluted; POM was sampled by collecting water from the open sea (approx. $3 \mathrm{~km}$ from the oyster cultures) at high tide and from $0.5 \mathrm{~m}$ below the surface; TOM was collected from Vire river freshwater $2 \mathrm{~km}$ upstream from the river mouth; MPB and ULV were sampled close to Site 4 (Fig. 1C). MPB was collected by scraping the first several $\mathrm{mm}$ of sediments, followed by an extraction using density centrifugation in Ludox HS$40 \%$ (SPCI). ULV was composed of both fresh and

Table 1. Description of sampling sites within oyster farms in the Bay of Veys, and presence/absence (+/-) of co-occurring species at each site. Mud: mud particles $(<65 \mu \mathrm{m})$ in surface $10 \mathrm{~cm}$ of sediments. O: oyster Crassostrea gigas, M: mussel Mytilus edulis, S: serpulid polychaete Pomatoceros lamarcki, B: barnacle Elminius modestus, T: terebellid polychaete Lanice conchilega, A: ascidian Ascidiella aspersa. ND: no data. See Fig. 1 for locations

\begin{tabular}{|c|c|c|c|c|c|c|c|c|c|c|}
\hline Site & Coordinates & Sediment & Elevation (m a.s.l.) & Mud & $\mathrm{O}$ & M & $\mathrm{S}$ & B & $\mathrm{T}$ & A \\
\hline 1 & $49^{\circ} 23^{\prime} 29.0^{\prime \prime} \mathrm{N}, 01^{\circ} 04^{\prime} 50.7^{\prime \prime} \mathrm{W}$ & Hard substrate & 1.75 & ND & + & + & + & + & - & - \\
\hline 2 & $49^{\circ} 23^{\prime} 23.7^{\prime \prime} \mathrm{N}, 01^{\circ} 05^{\prime} 08.9^{\prime \prime} \mathrm{W}$ & Pebbles & 1.70 & 5 & + & + & + & + & + & + \\
\hline 3 & $49^{\circ} 23^{\prime} 18.4^{\prime \prime} \mathrm{N}, 01^{\circ} 05^{\prime} 46.6^{\prime \prime} \mathrm{W}$ & Sand & 1.65 & 2 & + & + & + & + & + & + \\
\hline 4 & $49^{\circ} 22^{\prime} 56.6^{\prime \prime} \mathrm{N}, 01^{\circ} 05^{\prime} 58.9^{\prime \prime} \mathrm{W}$ & Sandy mud & 2.20 & 15 & + & + & + & + & + & + \\
\hline 5 & $49^{\circ} 22^{\prime} 11.1^{\prime \prime} \mathrm{N}, 01^{\circ} 06^{\prime} 05.3^{\prime \prime} \mathrm{W}$ & Sand & 2.20 & 1 & + & + & + & + & - & + \\
\hline 6 & $49^{\circ} 23^{\prime} 07.6^{\prime \prime} \mathrm{N}, 01^{\circ} 06^{\prime} 21.8^{\prime \prime} \mathrm{W}$ & Sand & 2.20 & 1 & + & + & + & + & + & - \\
\hline
\end{tabular}


freshly stranded leaves and collected was by hand. Annual means of food resource signatures were used rather than time-specific values, because isotopic signatures of organisms' tissues integrate information on assimilation of food over long time periods (Vanderklift \& Ponsard 2003).

Preparation and analysis. Organisms were kept alive for $12 \mathrm{~h}$ in filtered seawater from the study area, to allow for evacuation of their gut contents. Next, oysters and mussels were removed from their calcareous shells, serpulid worms were extracted from their tube, and barnacles were dissected with the aid of a binocular microscope to remove calcified wall-plates and appendages. Thus, no treatment with $\mathrm{HCl}$ was used to remove carbonates in order to avoid significant changes in $\delta^{15} \mathrm{~N}$ isotopic composition (Kaehler \& Pakhomov 2001). Subsequently, invertebrates were carefully washed with distilled water, and whole individuals were maintained at $-80^{\circ} \mathrm{C}$. Several studies have shown that isotopic signature of different tissues (gonad, muscle, and bone) reflect diet over different time periods, depending on tissue turnover rate (Sarakinos et al. 2002). Thus, to reduce factors that complicate explanation of variability, all tissues were ground together. For each site, individuals from the same species were arbitrarily placed in 2 groups: each group consisted of 10 individual oysters or mussels, 20 individual ascidians or polychaetes, or 50 barnacles. For POM and TOM, water was filtered on precombusted Whatman GF/F filters. Filters were freezedried, acidified with the vapour of $1 \mathrm{M} \mathrm{HCl}$ to remove carbonates, and kept at $-80^{\circ} \mathrm{C}$ until preparation for analysis. MPB was extracted from sediment using the method of Blanchard et al. (1988); ULV was collected by hand and treated in the same manner as the invertebrates. Samples were then freeze-dried and ground to powder with a pestle and mortar.

Approximately $1 \mathrm{mg}$ of invertebrate sample (2 analytical replicates) and $10 \mathrm{mg}$ of food-source sample (4 analytical replicates) were used for continuous flow isotope ratio spectrometry (CF-IRMS) analysis using a Europa Scientific ANCA-NT 20-20 Stable Isotope Analyser with ANCA-NT Solid/Liquid Preparation Module (Europa Scientific). The analytical precision ( $\mathrm{SD}, \mathrm{n}=5$ ) was $0.2 \%$ for both $\mathrm{N}$ and $\mathrm{C}$, as estimated from standards analysed along with the samples. Working standards were $1 \mathrm{mg}$ leucine prepared by freeze-drying $50 \mu \mathrm{l}$ of a $20 \mathrm{mg} \mathrm{ml}^{-1}$ stock solution in tin cups, and calibrated against 'Europa flour' and International Atomic Energy Agency (IAEA) standards N1 and N2. Carbon and nitrogen stable isotopic ratios were expressed in $\delta$ notation according the following equation:

$$
\delta X(\% \text { o })=\left[\left(R_{\text {sample }} \div R_{\text {standard }}\right)-1\right] \times 10^{3}
$$

where $X$ is ${ }^{13} \mathrm{C}$ or ${ }^{15} \mathrm{~N}$ and $R$ is the ratio ${ }^{13} \mathrm{C} /{ }^{12} \mathrm{C}$ or ${ }^{15} \mathrm{~N} /{ }^{14} \mathrm{~N}$. Standards used were Pee-Dee Belemnite (PDB) for carbon and atmospheric $\mathrm{N}_{2}$ for nitrogen.

Contribution of food resources to organisms' diets. As a quantitative approach to estimating the relative contribution of food sources to organisms' diets, we used a dual isotope, 4-source mixing model (IsoSource, Phillips \& Gregg 2003); this model provided the range of possible source contributions to a diet when there are too many sources to allow a unique solution. As is usual for studies dealing with food source contributions, fractionation-i.e. step-wise enrichment in ${ }^{13} \mathrm{C}$ and ${ }^{15} \mathrm{~N}$ at each trophic level-was considered here to be consistent for each species and equal to $1 \%$ and $3.5 \%$ per trophic level, respectively (e.g. Deegan \& Garritt 1997, Kaehler et al. 2000, Kharlamenko et al. 2001, Hsieh et al. 2002, Riera et al. 2002). The mixing model software IsoSource was used to calculate all possible combinations of source proportions that sum to $100 \%$ using a specified increment of $1 \%$ (after Benstead et al. 2006). Predicted isotope values of mixtures (i.e. organisms) were computed using linear mixing model equations that preserve mass balance. All combinations that matched within a specified tolerance of $0.1 \%$ were averaged to represent means of source proportions.

Data analyses. Mantel analyses were performed to test for spatial differences in stable isotopic signatures among sampling sites (Fortin \& Gurevitch 2001). These non-parametric tests are most appropriate when data are spatially auto-correlated; the tests are based on distance matrices and permutation tests, and are used to detect the presence of inherent spatial autocorrelation and to distinguish the effects of measured environmental conditions (i.e. elevation and percentage of mud in sediment) from other spatial effects. A 4-matrix Mantel test was performed to examine relationships between: (1) the variable distance matrix A that contains the differences in isotopic signatures among the 7 stations, (2) the distance matrix B that contains the Euclidian spatial distances among the 7 stations, and (3) 2 environmental-condition distance matrices that contain the differences between all pairs of data in elevation (matrix C) and mud content (matrix D). Before the normalized Mantel statistic r was computed, each distance matrix was first standardized individually by subtracting the mean of all elements in the matrix from each observation and then dividing by the SD (Fortin \& Gurevitch 2001). For instance, $\mathrm{r}_{\mathrm{AB}}$ was calculated by summing the cross products of the standardized (std) matrices A and B divided by $\mathrm{n}-1$ :

$$
\mathrm{r}=\frac{\sum_{\mathrm{i}=1}^{\mathrm{n}} \sum_{\mathrm{j}=1}^{\mathrm{n}} \operatorname{std}_{\mathrm{ij}} \mathrm{stdB}_{\mathrm{ij}}}{\mathrm{n}-1} \text { for } i \neq j
$$

The reference distribution was established by randomly shuffling the elements of the distance matrix B 
1000 times. The significance of the observed Mantel $r$ statistic was obtained by estimating the number of times that values of the reference distribution were smaller or greater than the Mantel statistic of the actual data, under the null hypothesis that the observed spatial variation could have been obtained by any random arrangement in space within the entire sampling area. These tests were performed with algorithms computed using Matlab 7.

In all statistical tests, a significance level of $\mathrm{p}<0.01$ was used to ensure a level of detection superior to the analytical precision $(0.2 \%)$.

\section{RESULTS}

\section{Inter-and intraspecific variations in isotopic signatures}

The isotopic signature of all species varied greatly among sampling sites, with interspecific variability being greater than intraspecific variability (Fig. 2). Isotopic signatures of ascidians Ascidiella aspersa differed markedly from those of the other 5 species, being characterised by low $\delta^{13} \mathrm{C}$ and the lowest ranges of both $\delta^{13} \mathrm{C}$ and $\delta^{15} \mathrm{~N}$. Polychaetes Lanice conchilega and Pomatoceros lamarcki had similarly high $\delta^{15} \mathrm{~N}$ values (approx. 12\%), but very different $\delta^{13} \mathrm{C}$ values (means -17.11 and $-19.04 \%$ respectively). Bivalves Crassostrea gigas and Mytilus edulis both had $\delta^{15} \mathrm{~N}$ values (approx. 9.5\%) lower than those of polychaetes, but $C$. gigas was slightly enriched in $\delta^{15} \mathrm{~N}$ and slightly depleted in $\delta^{13} \mathrm{C}$ relative to $M$. edulis (mean $\delta^{15} \mathrm{~N}$ : 10.02 and $9.37 \%$; mean $\delta^{13} \mathrm{C}$ : -19.32 and $-18.36 \%$, respectively). The barnacle Elminius modestus exhibited a wide spectrum of isotopic ranges, with $\delta^{13} \mathrm{C}$ values (mean $-18.12 \%$ ) similar to those of $M$. edulis and intermediate $\delta^{15} \mathrm{~N}$ values (mean $10.82 \%$ ). In addition, the isotopic signatures of E. modestus overlapped with those of $P$. lamarcki, $M$. edulis and, to a lesser extent, L. conchilega. Notably, stable isotopic signatures of $C$. gigas and $A$. aspersa did not overlap with values of other species.

Mantel tests were performed to test for spatial variability within the study area. Significant spatial variations in $\delta^{13} \mathrm{C}$ values were observed when all species were considered (Table 2). All species other than Ascidiella aspersa exhibited spatial differences. No spatial interactions were observed, meaning that the degree of spatial variability of most species was similar. On average, organisms at Site 1 were enriched in ${ }^{13} \mathrm{C}$ compared to those at Sites 7 and 5, which were depleted in ${ }^{13} \mathrm{C}$ (Fig. 2). These significant spatial variations could not be explained by percentage of mud or elevation (Table 2).

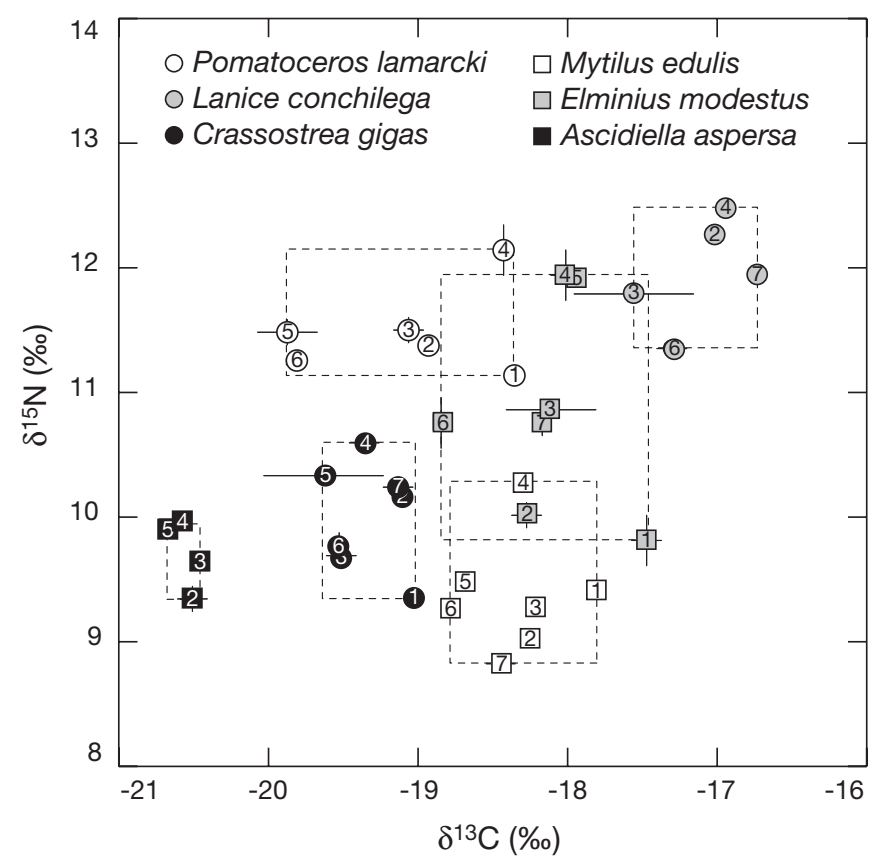

Fig. 2. Spatial variability of $\delta^{13} \mathrm{C}$ and $\delta^{15} \mathrm{~N}$ values in cooccurring filter-feeding species according to sampling site. Numbers refer to sampling site (see Fig. 1 for locations and Table 1 for physical descriptions). Error bars are SE. Dashed squares represent maximum and minimum $\delta^{13} \mathrm{C}$ and $\delta^{15} \mathrm{~N}$ values for each species within the oyster culture area

Although there were no significant spatial variations when all species were considered, the $\delta^{15} \mathrm{~N}$ values of Crassostrea gigas, Elminius modestus and Lanice conchilega exhibited significant spatial variations with significant spatial interaction (Table 2). This means that no common pattern of spatial variation in $\delta^{15} \mathrm{~N}$ was discernable for these 3 species; however, organisms at Site 4 were systematically enriched in ${ }^{15} \mathrm{~N}$. When statistically significant, spatial variations were explained by the percentage of mud (Table 2).

\section{Spatial variations in food source contributions}

The mixing model was applied to each of the sampling sites to determine spatial variability of food source contribution. Mean annual signatures of identified food sources revealed that ranges of $\delta^{13} \mathrm{C}$ values were around $12 \%$ (from approx. -29 to $-17 \%$ ); TOM, POM and sedimented organic matter (ULV and MPB) were easily discriminated. In contrast, ranges of $\delta^{15} \mathrm{~N}$ values were less than $5 \%$ (from approx. 5 to $10 \%$ ); POM was discriminated from ULV, and to a lesser extent from TOM and MPB (Fig. 3). This suggested that the model was more sensitive to changes in the $\delta^{15} \mathrm{~N}$ signatures of organisms than to changes in $\delta^{13} \mathrm{C}$ signatures: small variations in $\delta^{15} \mathrm{~N}$ values of consumers 
Table 2. Mantel test for $\delta^{13} \mathrm{C}$ and $\delta^{15} \mathrm{~N}$ stable isotopic composition of organisms in the Bay of Veys. Mantel correlation value calculated after 1000 permutations. Spatial: spatial variation, Mud: mud content. ${ }^{*} \mathrm{p}<0.01,{ }^{* *} \mathrm{p}<0.001$

\begin{tabular}{|lrlll|}
\hline Stable isotope & & Spatial & Mud & Elevation \\
\hline $\boldsymbol{\delta}^{13} \mathbf{C}$ & & & & \\
All species & 36 & $0.099^{*}$ & 0.093 & 0.055 \\
Species $\times$ Spatial & 36 & 0.312 & & \\
Crassostrea gigas & 7 & $1.298^{* *}$ & 0.268 & 0.449 \\
Mytilus edulis & 7 & $1.796^{* *}$ & 0.183 & 0.669 \\
Pomatoceros lamarcki & 6 & $1.523^{* *}$ & 0.627 & 0.903 \\
Elminius modestus & 7 & $1.027^{*}$ & 0.306 & 0.232 \\
Lanice conchilega & 5 & $1.489^{* *}$ & 0.462 & 0.745 \\
$\boldsymbol{\delta}^{15} \mathbf{N}$ & & & & \\
All species & 36 & 0.080 & 0.135 & 0.013 \\
Species $\times$ Spatial & 36 & $0.165^{* *}$ & & \\
Crassostrea gigas & 7 & $1.145^{* *}$ & $0.749^{*}$ & 0.324 \\
Mytilus edulis & 7 & 0.464 & $1.151^{* *}$ & 0.155 \\
Pomatoceros lamarcki & 6 & 0.715 & $1.136^{* *}$ & 0.526 \\
Elminius modestus & 7 & $1.142^{* *}$ & $1.228^{* *}$ & 0.309 \\
Lanice conchilega & 5 & $1.054^{* *}$ & $0.979^{* *}$ & 0.229 \\
\hline
\end{tabular}

induced large changes in estimates of resource contributions. Consequently, species with non-significant (Mytilus edulis, Pomatoceros lamarcki) or low (Ascidiella aspersa) spatial $\delta^{15} \mathrm{~N}$ variation exhibited small changes in food source contributions (Fig. 4). For example, food source contributions to $M$. edulis ranged from 32.2 to $55.3 \%$ and 43.2 to $64.3 \%$ for POM and $\mathrm{MPB}$, respectively, with a few percent for ULV and MPB (Site 4 excluded). In contrast, food source contributions to Elminius modestus ranged from 4 to $64.9 \%$ and 13.4 to $73.7 \%$ for ULV and MPB, respectively. Crassostrea gigas and Lanice conchilega exhibited intermediate values between these 2 extremes (Fig. 4).

\section{DISCUSSION}

\section{Small-scale spatial variability}

Small-scale spatial variations in stable isotopic signatures are not commonly investigated in food web studies. Studies have focused mainly on large-scale spatial variability, such as on differences between distinct coastal bay systems (Kang et al. 2003) or on relationships among large regions (e.g. freshwater marshes, river banks, salt marshes, intertidal mud flats with seagrass, mangroves) of estuarine areas (Kikuchi \& Wada 1996, Deegan \& Garritt 1997, Marguillier et al. 1997). Hsieh et al. (2002) considered small-scale spatial variability by comparing 2 sites within a single intertidal flat in a mangrove estuary; they interpreted differences in trophic structure from the $\delta^{13} \mathrm{C}$ and $\delta^{34} \mathrm{~S}$ signatures of prey and predators, which possibly resulted from down-shore distance from the tidal flat and time of immersion. In a Mediterranean semienclosed coastal basin, Vizzini \& Mazzola (2006) observed small differences in consumers' signatures associated with changes in environmental features (hydrodynamic regime, coverage of vegetation and open-sea influence). Overall, small-scale spatial variability is highly related to hydrodynamic processes. In our macrotidal estuary, the hydrodynamic regime largely determined the origin, distribution and transfer of organic matter within the shellfish culture area investigated. The diets of suspension-feeding species were mixtures of organic matter from several sources that were suspended in the water column or resuspended by tidal currents (Prins et al. 1998). Because of the ebb and flow of tidal currents that governed cycles of deposition and resuspension, it is unrealistic to predict the small-scale origin of sediment-derived organic matter. Mantel tests are a solid statistical tool designed to underline inherent spatial variability within an area and to point out auto-correlation (Fortin \& Gurevitch 2001); in this study, not all spatial variation in $\delta^{13} \mathrm{C}$ could be explained by environmental factors (i.e. elevation and percentage of mud), indicating the involvement of other sources of variability governed by hydrodynamic processes.

Spatial trends in $\delta^{13} \mathrm{C}$ variation among sampling sites have often been related to physical effects such as tidal amplitude or hydrobiology (Hsieh et al. 2002). In the

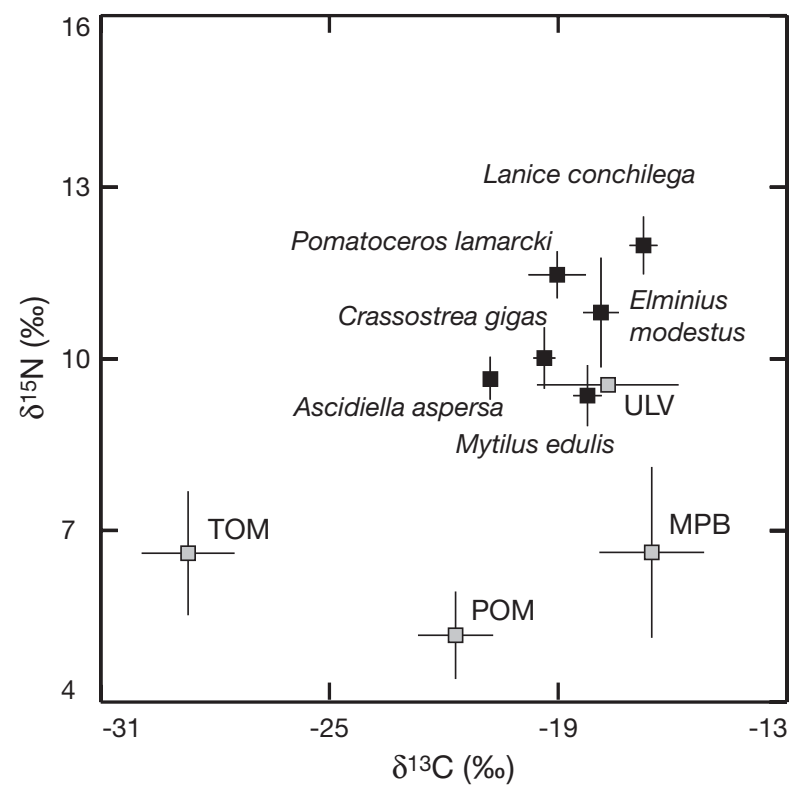

Fig. 3. Mean stable isotope ratios $\left(\delta^{13} \mathrm{C}\right.$ vs. $\left.\delta^{15} \mathrm{~N}\right)$ of organisms (black squares) and organic matter sources (grey squares) from 7 sampling sites. Error bars are SD. POM: particulate organic matter; TOM: terrestrial organic matter; ULV: Ulva; MPB: microphytobenthos. Note: consumer $\delta^{13} \mathrm{C}$ and $\delta^{15} \mathrm{~N}$ values were not corrected for trophic fractionation 

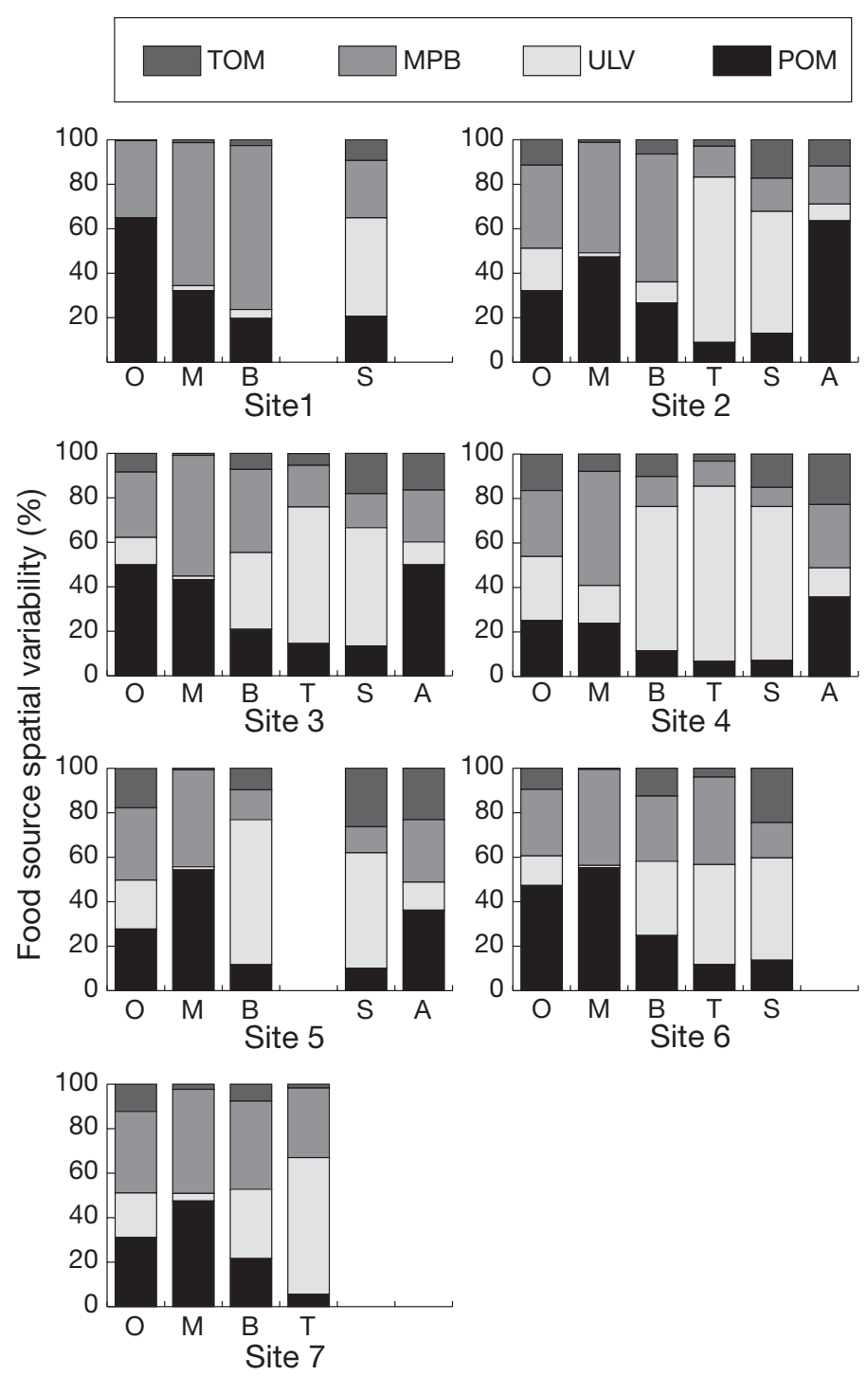

Fig. 4. Spatial variability of mean relative contributions (\%) of foods sources for each species as estimated by the 4-sources mixing model. Food sources-TOM: terrestrial organic matter, MPB: microphytobenthos, ULV: Ulva and POM: marine particulate organic matter. Species-O: oyster Crassostrea gigas, M: mussel Mytilus edulis, B: barnacle Elminius modestus, T: terrebelid polychaete Lanice conchilega, S: serpulid polychaete Pomatoceros lamarcki and A: ascidian Ascidiella aspersa

present study, we found that although elevation may have no effect on variability of organisms' signatures, the percentage of mud in sediment could partly explain variation. There was no interaction between species and spatial effects with regard to $\delta^{13} \mathrm{C}$ variation (Table 2), indicating that all species become enriched at the same site; however, enrichment of $\delta^{13} \mathrm{C}$ in the northernmost site (i.e. Site 1 ) is probably derived from 2 food sources: ULV (for barnacles and polychaetes), and MPB (for bivalves and ascidians). Differences in the $\delta^{13} \mathrm{C}$ signatures of MPB and ULV were insufficient to detect the source of variation. Overall, the ${ }^{13} \mathrm{C}$ signatures of suspension-feeding species became more enriched towards Sites 1 and 2 (hard substrata), suggesting that species occurring in the north of the sampling area consumed more $\mathrm{MPB}$, or that the contribution of TOM (which is very depleted in $\delta^{13} \mathrm{C}$ ) is greater towards the south (as was suggested by Costil et al. [2005] in their study on spatial variations in oysters in the Bay of Veys). Alternatively, species assemblages may differ fundamentally between hard substrata and soft bottom environments (Lewis 1964), leading to variable $\delta^{13} \mathrm{C}$ among sites. According to Lewis (1964), rocky plates and pebbles host numerous sessile epibionts - largely suspension-feeders - which affect competition pressure for cultivated oysters and associated fauna. In the present study, variations in $\delta^{15} \mathrm{~N}$ did not show similar patterns among species, except at Site 4 where stable isotopic signatures of organisms became more enriched. Because this site was characterized by a higher content of fine particles < $60 \mu \mathrm{m}$ (see Table 1), we suggest that species feeding in this closed area were more likely to feed on particles resuspended from the sediment (i.e. MPB and ULV). This could also include heterotrophic microorganisms (bacteria, ciliates, protozoans, nematodes) classically associated and resuspended with mud (Shimeta et al. 1995).

The present study demonstrates that variations in the relative contribution of food resources could be principally attributable to sampling site. For example, spatial variability in food source reached $60 \%$ for the contribution of ULV to barnacles' diet, and $40 \%$ for the contribution of POM to oysters' diet. Consequently, we recommend a more cautious approach for studies designed to investigate food-web structure and trophic linkages within a community using single-point sampling (see for example Kharlamenko et al. 2001, Riera et al. 2002). Estimates of small-scale spatial variability are thus of primary importance to the improvement in robustness of interpretations of trophic relationships and interspecific competition for food.

\section{Food resource partitioning in suspension-feeding species}

Contrary to what has been traditionally assumed, we found that co-occurring suspension-feeding species did not have the same isotopic signatures. Cultivated oysters Crassostrea gigas do not necessarily compete for food with associated epibionts (i.e. Pomatoceros lamarcki, Lanice conchilega, Mytilus edulis, Elminius modestus and Ascidiella aspersa). Food resource isotopic signatures provided a valuable isotopic baseline to assist with understanding trophic relationships 
among organisms in this system (Post 2002). POM and MPB may support large parts of the diets of cultivated and wild suspension-feeders, especially bivalves and ascidians. In addition, ULV made extremely variable contributions to suspension-feeders' diets, contributing more to the diets of polychaetes and barnacles as revealed by these species' high $\delta^{15} \mathrm{~N}$ values. Contrary to other selected food resources, TOM did not contribute greatly to the diets of suspension-feeding species; however, the contribution of TOM was less variable than that of other food sources.

In shellfish estuaries, both terrestrial and marine organic matter, along with macroalgae and MPB, are classically recognized as the main food sources for suspension-feedings species (Riera \& Richard 1997, Riera 1998 and references therein). It is well known that marine phytoplankton contributes to suspensionfeeders' diets; for example, in Marennes-Oléron Bay (French Atlantic coast), it was revealed that $70 \%$ of total annual cockle production originated from MPB sources (Sauriau \& Kang 2000). However, the contribution of MPB is still debated (Kang et al. 2003). The contributions of TOM to suspension-feeders' diets are reported to be highly variable. Isotopic approaches have proven the importance of organic matter from terrigenous sources to suspension-feeders in large estuaries on the Atlantic coast, such as MarennesOléron Bay (Riera \& Richard 1997). In contrast, consumer dependence on riverine TOM was minimal in the Plum Island Sound estuary (USA) (Deegan \& Garritt 1997). In our macrotidal estuary, moderate freshwater inputs are largely overpowered during high tides, and TOM did not appear to contribute greatly to the diets of oysters and other suspension-feeders. Our $\delta^{15} \mathrm{~N}$ results also demonstrated that, despite being of unequal importance, contributions of green algal to the diets of suspension-feeding species (shown by the example of Ulva sp.) could not be excluded. This was shown especially for polychaetes Lanice conchilega and Pomatoceros lamarcki and the barnacle Elminius modestus. In coastal ecosystems, a significant fraction of macroalgal biomass is dislodged and fragmented by currents and waves before being integrated in sediments. Macroalgal fragments may thus enter coastal food webs through different pathways, for example through detrital food chains, as shown in MarenneOléron Bay (Riera 1998) and in Possyet Bay, Russia (Kharlamenko et al. 2001).

Quantitative estimates via the 4-sources mixing model (Philipps \& Gregg 2003) should be interpreted cautiously. Indeed, Moseman et al. (2004) recently pointed out that in estuarine environments, the number of potential primary producers contributing to the food web is often greater than expected, and that the more potential sources of food, the greater the uncer- tainty in determining which sources make important contributions to a diet. In this regard, mathematical solutions of the mixing model are not always biologically relevant; consumers' isotopic signatures that can be identified by 4 sources will always have a solution that involves 4 food items, even if a solution can be found with only 3 of them. In this study, bivalves and ascidians fed only on TOM, POM and MPB, but the contribution of ULV could not be excluded for barnacles and polychaetes on the basis of $\delta^{15} \mathrm{~N}$ values. Therefore, quantitative estimates of ULV contributions for bivalves and ascidians should be considered cautiously. In addition, we demonstrated that ranges of $\delta^{15} \mathrm{~N}$ (from approx. 5\% for POM to $10 \%$ for ULV) were much smaller than ranges of $\delta^{13} \mathrm{C}$ (from approx. $-29 \%$ for TOM to $17 \%$ for ULV or MPB). Consequently, small variations in consumers' $\delta^{15} \mathrm{~N}$ values induced large variations in estimates of ULV contribution, whereas estimates of POM and MPB contributions remained less sensitive. Estimates using the mixing model are also limited by fractionation values; although step-wise enrichment in ${ }^{13} \mathrm{C}$ and ${ }^{15} \mathrm{~N}$ at each trophic level is generally assumed to be consistent among species (e.g. Deegan \& Garritt 1997, Kaehler et al. 2000, Kharlamenko et al. 2001, Hsieh et al. 2002, Riera et al. 2002), it is increasingly considered to be a potential source of variation when determining sources of nutrition and trophic relationships (Vander Zanden \& Rasmussen 2001, Vanderklift \& Ponsard 2003).

\section{Feeding processes and isotopic signatures}

The studied species exhibited differences in intraand interspecific variability, even though they all belonged to the same feeding guild; thus, several suspension-feeding species can potentially utilize the same food resources without having similar isotopic signatures by consuming the food items in different proportions. Our isotopic results support the concept of small-scale trophic plasticity of suspension-feeding species. Trophic plasticity is a common mechanism in consumers, which allows them to adapt to environmental availability of food items (Pinnegar \& Polunin 2000). This was recently demonstrated at a similar scale to that of the present study in a semi-enclosed Mediterranean basin for fish species associated with seagrass meadows (Vizzini \& Mazzola 2006). There was an obvious contrast between the intraspecific variability of the barnacle Elminius modestus and that of the ascidian Ascidiella aspersa, whereas other suspension feeders exhibited intermediate intraspecific ranges in $\delta^{13} \mathrm{C}$ and $\delta^{15} \mathrm{~N}$. The limited intraspecific variability of ascidian signatures suggested that $A$. aspersa is less capable of trophic plasticity (thus tending to be a trophic specialist) than other suspension feeding 
species such as E. modestus (trophic generalist). So, regardless of sampling site or composition of available food resource, the ascidian exhibited the same isotopic signature; in contrast, the signature of the barnacle was dependent on sampling site.

Even if all 6 species belong to the same suspensionfeeding guild, ecophysiological studies on suspensionfeeders have emphasized that there are great differences in filtration rates and in retention efficiencies (see review by Riisgård \& Larsen 2000); ascidians and bivalves are active suspension-feeders, extracting particles from the water with bands of active cilia, whereas polychaetes and barnacles do not actively pump water through a filter. For instance, the great trophic plasticity of the barnacle E. modestus may result from their feeding mechanism: specifically, extension of feather-like legs (cirri) into the ambient flow allows them to feed on large motile particles such as Artemia nauplii as well as on small particles (Pullen \& LaBarbera 1991). Thus, we suggest that the barnacle population showed a large degree of intraspecific variability because it was composed of generalist individuals all consuming a wide range of food items (Bolnick et al. 2003). Intraspecific variability in barnacles' isotopic signature was closely related to spatial variability of food resources, because barnacles do not possess any particle selection mechanism.

The consistent signature of ascidians, which likewise do not select particles (instead trapping particles on a continually-produced mucus net, Petersen et al. 1997), did not support the same interpretation. We propose that ascidians do not feed continuously when submerged. In our intertidal estuarine bay, resuspension of inorganic particles from the sediment, owing to high velocity currents during ebb or flow tide, generates high concentrations in the water column that are known to interfere with the feeding activity of suspensionfeeding species in general (e.g. Hawkins et al. 1996). It is likely that ascidians could be more affected by these conditions than other species, and that they filter-feed in the water column only around high tide when hydrodynamic conditions are most stable, thereby consuming lower amounts of inorganic particles. A good example of trophic plasticity is given through comparison of oysters with mussels: both species have very closed feeding processes and a capacity for particle selection (Riisgård \& Larsen 2000). Oysters exhibited larger spatial variations in isotopic signatures than did mussels. Both species fed on the same mixture, but oysters appeared to be capable of greater trophic plasticity than did mussels, for which MPB and POM almost exclusively contributed to the diet at all sampling sites.

Unexpectedly, both serpulid and terebellid polychaete species probably fed on Ulva fragments. The tubiculous terebellid Lanice conchilega colonized soft- sediments underneath oyster tables. Its sand tube protrudes above the sediment surface by a few centimetres (Ropert \& Dauvin 2000); thus, it could have easily accessed both MPB and green macroalgae fragments that were resuspended. Particles are collected through funnel-shaped tentacular filaments. In contrast to specimens colonizing the sediment, worms adhering to oyster shells at about 30 to $40 \mathrm{~cm}$ above the sediment had consumed lower proportions of MPB, as suggested by more depleted $\delta^{13} \mathrm{C}$ values.

\section{CONCLUSIONS}

The diets of suspension-feeding species that inhabit intertidal areas were largely dependent on the nature and quantity of the organic particles transported and resuspended by the flood tide during immersion. Our analysis of small-scale spatial variability in the isotopic composition of suspension-feeding species provided a broader perspective for the determination of dietary overlap and potential competition for food between species. We demonstrated that cultivated and wild suspension-feeders do not necessary compete for food, and that feeding mechanisms are of fundamental importance in understanding the partioning of food resources and dietary overlap of co-occurring species. We also provided evidence that a sampling design capturing only an instantaneous snapshot of stable isotopic signatures could lead to the misinterpretation of interspecific trophic relationships in an ecosystem.

Acknowledgements. This study was supported by a postgraduate fellowship funded by the regional council of Basse Normandie within the POMOYSTER program financed by Direction Régionale de l'Environnement (DIREN), Agence de l'eau and Direction Régionale des Affaires Maritimes (DRAM). We are grateful to Dr. C. M. Scrimgeour and M. P. Bataillé for technical assistance with stable isotope analysis and E. Leroullier for assistance with laboratory preparation. We acknowledge Dr. J. E. Purcell and Dr. S. M. Gaudron for English corrections. Thanks are due to 3 anonymous referees for helpful comments.

\section{LITERATURE CITED}

Benstead JP, March JG, Fry B, Ewel, KC, Pringle CM (2006) Testing isosource: stable isotope analysis of a tropical fishery with diverse organic matter sources. Ecology 87:326-333

Blanchard G, Chrétiennot-Dinet MJ, Dinet A, Robert JM (1988) Méthode simplifiée pour l'extraction du microphytobenthos des sédiments marins par le gel de silice Ludox. CR Biol 307:569-576

Bolnick D, Svanback R, Fordyce J, Yang L, Davis J, Hulsey C, Forister C (2003) The ecology of individuals: incidence and implications of individuals specialization. Am Nat 161:1-28

Costil K, Royer J, Ropert M, Soletchnik P, Mathieu M (2005) 
Spatio-temporal variations in biological performances and summer mortality of the Pacific oyster Crassostrea gigas in Normandy (France). Helgol Mar Res 59:286-300

Crawford CM, Macleod CKA, Mitchell IM (2003) Effects of shellfish farming on the benthic environment. Aquaculture 224:117-140

Deegan LA, Garritt RH (1997) Evidence for spatial variability in estuarine food webs. Mar Ecol Prog Ser 147:31-47

DeNiro MJ, Epstein S (1978) Influence of diet on the distribution of carbon isotopes in animals. Geochim Cosmochim Acta 42:495-506

Fortin MJ, Gurevitch J (2001) Mantel tests: spatial structure in field experiments. In: Scheiner SM, Gurevitch J (eds) Design and analysis of ecological experiments. Oxford University Press, New York, p 308-326

Fry B (2006) Stable isotope ecology. Springer, Heidelberg

Guest MA, Connolly RM (2004) Fine-scale movement and assimilation of carbon in saltmarsh and mangrove habitat by resident animals. Aquat Ecol 38:599-609

Hawkins AJS, Smith RFM, Bayne BL, Heral M (1996) Novel observations underlying the fast growth of suspensionfeeding shellfish in turbid environments: Mytilus edulis. Mar Ecol Prog Ser 131:179-190

Hsieh HL, Kao WY, Chen CP, Liu PJ (2000) Detrital flows through the feeding pathway of the oyster Crassostrea gigas in a tropical shallow lagoon: $\delta^{13} \mathrm{C}$ signals. Mar Biol 136:677-684

Hsieh HL, Chen CP, Chen YG, Yang HH (2002) Diversity of benthic organic matter flows through polychaetes and crabs in a mangrove estuary: $\delta^{13} \mathrm{C}$ and $\delta^{34} \mathrm{~S}$ signals. Mar Ecol Prog Ser 227:145-155

Kaehler S, Pakhomov EA (2001) Effects of storage and preservation on the $\delta^{13} \mathrm{C}$ and $\delta^{15} \mathrm{~N}$ signatures of selected marine organisms. Mar Ecol Prog Ser 219:299-304

Kaehler S, Pakhomov EA, McQuaid CD (2000) Trophic structure of the marine food web at the Prince Edward Islands (Southern Ocean) determined by $\delta^{13} \mathrm{C}$ and $\delta^{15} \mathrm{~N}$ analysis. Mar Ecol Prog Ser 208:13-20

Kang CK, Kim JB, Lee KS, Lee PY, Hong JS (2003) Trophic importance of benthic microalgae to macrozoobenthos in coastal bay systems in Korea: dual stable $\mathrm{C}$ and $\mathrm{N}$ isotope analyses. Mar Ecol Prog Ser 259:79-92

Kharlamenko VI, Kiyashko SI, Imbs AB, Vyshkvartzev DI (2001) Identification of food sources of invertebrates from the seagrass Zostera marina community using carbon and sulfur stable isotope ratio and fatty acid analyses. Mar Ecol Prog Ser 220:103-117

Kikuchi E, Wada E (1996) Carbon and nitrogen stable isotope ratios of deposit-feeding polychaetes in the Nanakita River Estuary, Japan. Hydrobiologia 321:69-75

Lesser MP, Shumway SE, Cucci T, Smith J (1992) Impact of fouling organisms on mussel rope culture: interspecific competition for food among suspension-feeding invertebrates. J Exp Mar Biol Ecol 165:91-102

Lewis JR (1964) The ecology of rocky shores. English University Press, London

Lundsgaard C, Olesen M (1996) The origin of sedimenting detrital matter in a coastal system. Limnol Oceanogr 42: 1001-1005

Marguillier S, van der Velde G, Dehairs F, Hemminga MA, Rajagopal S (1997) Trophic relationships in an interlinked mangrove-seagrass ecosystem as traced by $\delta^{13} \mathrm{C}$ and $\delta^{15} \mathrm{~N}$. Mar Ecol Prog Ser 151:115-121

Moseman SM, Levin LA, Currin C, Forder C (2004) Colonization, succession, and nutrition of macrobenthic assemblages in a restored wetland at Tijuana Estuary, California. Estuar Coast Shelf Sci 60:755-770
Petersen JK, Schou O, Thor P (1997) In situ growth of the ascidian Ciona intestinalis (L.) and the blue mussel Mytilus edulis in an eelgrass meadow. J Exp Mar Biol Ecol 218:1-11

Phillips DL, Gregg JW (2003) Source partitioning using stable isotopes: coping with too many sources. Oecologia 136: 261-269

Pinnegar JK, Polunin NVC (2000) Contributions of stable-isotope data to elucidating food webs of Mediterranean rocky littoral fishes. Oecologia 122:399-409

Post DM (2002) Using stable isotopes to estimate trophic position: models, methods, and assumptions. Ecology 83:703-718

Prins TC, Smaal AC, Dame RF (1998) A review of feedbacks between bivalve grazing and ecosystem processes. Aquat Ecol 31:349-359

Pullen J, LaBarbera M (1991) Modes of feeding in aggregations of barnacles and the shape of aggregations. Biol Bull (Woods Hole) 181:442-452

Riera P (1998) $\delta^{15} \mathrm{~N}$ of organic matter sources and benthic invertebrates along an estuarine gradient in MarennesOléron bay (France): implications for the study of trophic structure. Mar Ecol Prog Ser 166:143-150

Riera P, Richard P (1996) Isotopic determination of food sources of Crassostrea gigas along a trophic gradient in the estuarine Bay of Marennes-Oléron. Estuar Coast Shelf Sci 42:347-360

Riera P, Richard P (1997) Temporal variation of $\delta^{13} \mathrm{C}$ in particulate organic matter and oyster Crassostrea gigas in Marennes-Oléron Bay (France): effect of freshwater inflow. Mar Ecol Prog Ser 147:105-115

Riera P, Stal LJ, Nieuwenhuize J (2002) $\delta^{13} \mathrm{C}$ versus $\delta^{15} \mathrm{~N}$ of cooccurring molluscs within a community dominated by Crassostrea gigas and Crepidula fornicata (Oosterschelde, The Netherlands). Mar Ecol Prog Ser 240:291-295

Riisgård HU, Larsen PS (2000) Comparative ecophysiology of active zoobenthic filter feeding, essence of current knowledge. J Sea Res 44:169-193

Rolff C (2000) Seasonal variation in $\delta^{13} \mathrm{C}$ and $\delta^{15} \mathrm{~N}$ of size-fractionated plankton at a coastal station in the northern Baltic proper. Mar Ecol Prog Ser 203:47-65

Ropert M, Dauvin JC (2000) Renewal and accumulation of a Lanice conchilega (Pallas) population in the baie des Veys, western Bay of Seine. Oceanol Acta 23:529-546

Sarakinos HC, Johnson ML, Vander Zanden MJ (2002) A synthesis of tissue-preservation effects on carbon and nitrogen stable isotope signatures. Can J Zool 80:381-387

Sauriau PG, Kang CK (2000) Stable isotope evidence of benthic microalgae-based growth and secondary production in the suspension feeder Cerastoderma edule (Mollusca, Bivalvia) in the Marennes-Oléron Bay. Hydrobiologia 440: 317-329

Shimeta J, Jumars PA, Lessard EJ (1995) Influences of turbulence on resuspension feeding by planktonic protozoa; experiments in laminar shear fields. Limnol Oceanogr 40: $845-859$

van de Koppel J, Herman PMJ, Thoolen P, Heip CHR (2001) Do alternate stable states occur in natural ecosystems? Evidence from a tidal flat. Ecology 82:3449-3461

Vander Zanden MJ, Rasmussen JB (2001) Variation in $\delta^{15} \mathrm{~N}$ and $\delta^{13} \mathrm{C}$ trophic fractionation: implications for aquatic food web studies. Limnol Oceanogr 46:2061-2066

Vanderklift MA, Ponsard S (2003) Sources of variation in consumer-diet $\delta^{15} \mathrm{~N}$ enrichment: a meta-analysis. Oecologia 136:169-182

Vizzini S, Mazzola A (2006) Sources and transfer of organic matter in food webs of a Mediterranean coastal environment: evidence for spatial variability. Estuar Coast Shelf Sci 66:459-467 